\title{
感染制御を目的とした病院内の細菌学的環境調査
}

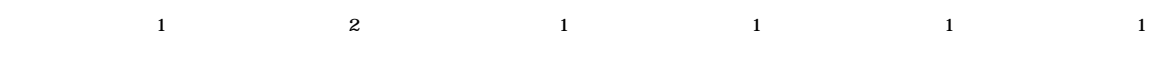 \\ 並木勇太 ${ }^{1}$, 山中義裕 ${ }^{1}$, 熊木雄一 ${ }^{1}$, 諏訪淳- ${ }^{1}$, 奥山 清 $^{2}$, \\ 明石貴雄 ${ }^{2}$, 那須 豊 ${ }^{2}$, 小山正晴 ${ }^{2}$, 内海健太 ${ }^{2}$, \\ 若杉和倫 $^{2}$, 高沢謙二 ${ }^{2}$, 笹津備規 ${ }^{1}$ \\ 東京薬科大学薬学部病原微生物学教室 ${ }^{1}$ \\ 東京医科大学病院八王子医療センター感染症対策委員会 ${ }^{2}$
}

\section{Microbial Surveillance Conducted for Infection Control at a Hospital}

\author{
Koji Narui ${ }^{1}$, Norifumi Matsunaga ${ }^{2}$, Norihisa Noguchi ${ }^{* 1}$, Junichi Nojo ${ }^{1}$, Takashi Tomizawa ${ }^{1}$, \\ Takayuki Ishii ${ }^{1}$, Yuta Namiki ${ }^{1}$, Yoshihiro Yamanaka ${ }^{1}$, Yuichi Kumaki ${ }^{1}$, Junichi Suwa ${ }^{1}$, \\ Kiyoshi Okuyama², Takao Akashi'2, Yutaka Nasu², Masaharu Koyama², \\ Kenta Utsumi ${ }^{2}$, Kazunori Wakasugi ${ }^{2}$, Kenji Takazawa ${ }^{2}$ and Masanori Sasatsu ${ }^{1}$ \\ Department of Microbiology, School of Pharmacy, Tokyo University of Pharmacy and Life Science ${ }^{1}$ \\ Infection Control Committee, Hachioji Medical Center, Tokyo Medical University ${ }^{2}$
}

$$
\left[\begin{array}{l}
\text { Received October 23, } 2007 \\
\text { Accepted January 24, } 2008
\end{array}\right]
$$

For infection control purposes, we conducted microbial surveillance targeting the air, floors, and sinks at approximately 250 locations from 1999 to 2004 . A nnual changes in the average number of microbial isolates from air, floor, and sink samples were not correlated but changes in particular sampling items were correlated. Hospital wards where there was greater movement of people produced larger average numbers of isolates than other parts of the hospital, for example examination rooms. We found that the average number of isolates from air and floor samples was higher when a new hospital ward was under construction as well as just after its opening. Methicillin-resistant Staphylococcus aureus (MRSA) was frequently isolated from floor samples (68.8\%) and Pseudomonas aeruginosa was isolated from both floor (10.3\%) and sink (89.7\%) samples. The numbers of MRSA and Pseudomonas aeruginosa isolated from hospital ward samples were larger than those from other parts of the hospital.

Our microbial surveillance clearly showed that the distribution of environmental bacteria changed in the hospital overall rather than for individual units and was affected by human activity and environmental changes. Furthermore, the species of bacteria isolated from the air, floor, and sink samples were different. Therefore, our results suggest that it is important to address the sanitization of the hospital environment as a whole, not on a ward by ward basis.

Key words - Microbial surveillance, infection control, Pseudomonas aeruginosa, methicillin-resistant Staphylococcus aureus (MRSA)

\section{緒言}

医療の進歩に伴って, 高齢者, がん患者や移植患者の ような易感染性患者か増加している．㫕れゆえ，メチシ リン耐性黄色ブドウ球菌(MRSA) バンコマイシン耐性腸 球菌(VRE)や多剂耐性緑膿菌のような薬剂の乱用によっ て生み出されてきた薬阂耐性菌ばかりでなく,Serratia，
Burkholderia ,Stenotrophomonas ,Citrobacter , Acinetobac-

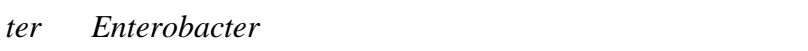
菌も主要な院内感染・日和見感染の原因菌になってい $3^{1-3)}$. 院内感染の感染経路は, 主に保菌者, 医療従事 者や環境との接触によると考えられている．なかでも， 環境を起因とする感染は光の検出・立証が難しく, 環境 は感染リスクとして認識されにくい.また，Centers for Disease Control and Prevention(以下, CDC と略す)の医療 
施設における環境感染管理のガイドラインには「空気， 水，環境表面の無作為でかつ目的の不明瞭な微生物学的 な試料採取は必要ない」ことが勧告されている4)，弚の ため，環境が感染リスクとなりえず，細菌学的環境調査 は必要がないように認識されている．しかし，CDCの 同ガイドラインには「疫学調査の一部として，あるいは 危機的環境状況下での污染の検出あるいは減少を確認す るためには微生物学的な試料採取は必要である」ことが あわせて勧告されている4．実際，環境表面や空気から 病原体が分離されている ${ }^{5-8)}$. 兴のため, 院内の一部の 環境は重要な感染源であり，感染経路の一つとして考え られる。

したがって, 病院環境における細菌学的環境調査は, (1)院内で流行，いわゆるアウトブレイクが起こった際 に，細菌分布のベースラインとして，(2)院内感染・日和 見感染の原因菌の検出頻度が高い場所を特定すること で, 衛生的な環境保全の指標として活用するための情報 をもたらす．乥こで，われわれは 1999 年から 2004 年の 6 年間にわたり, 空中・床・流しの約 250 力所を調査 し, 疫学的解析を行った。

\section{材料・方法}

\section{1. 調査期間と調查場所}

1999 年 5 月から 2004 年 7 月に東京医科大学八王子医 療センターにて細菌学的環境調査を行った。調査は 4 月 から 9 月の春期から秋期に行い，調査場所ごとに毎年同 一の時期に行った . 調査場所は $\mathrm{A}$ 棟の入院病棟である 1 階西(A 1西: 感染症), 3階東(A 3 東: 循環器内科)，3 階西 (A 3 西: 心藏血管外科, 循環器内科, 神経内科, 内科混合), 4階東 (A 4 東: 血液内科, 呼吸器内科, 婦 人科, 救命救急部)，4階西(A 4西：産科)，B 棟の入院 病棟である2階東(B2 東: 整形外科, 形成外科)，2階 東(B 2西：脳神経外科, 口腔外科, 神経内科, 外科系混 合), 3 階東(B 3 東: 藏器移植外科, 一般外科, 皮膚科, 救命救急部), 3 階西 (B 3 西 : 消化器外科, 救命救急部), 4階東(B 4 東: 耳鼻咽喉科, 頭頸部外科, 泌尿器科)，4 階西(B 4西: 呼吸器外科, 腎蔵内科, 救命救急部)と, 兴の他の病院施設として, 放射線科, 手術室, 内視鏡検 査室, 外来, 廊下, 透析室, 薬剂部, 救急外来, 集中治 療室において, 空中浮遊菌検査, 床の拭き取り検査や流 しの拭き取り検査，合計約 250 力所を調査した(図 1) . ただし，移設(A 1西とB 4西の 2002年から 2004 年)や 業務上検体採取が困難な場合は調査を行わなかった .

\section{2. 調査対象と調査方法}

主要な院内感染原因菌は好気性および通性嫌気性菌で あること，芽胞非形成の嫌気性菌は一般の好気的環境下

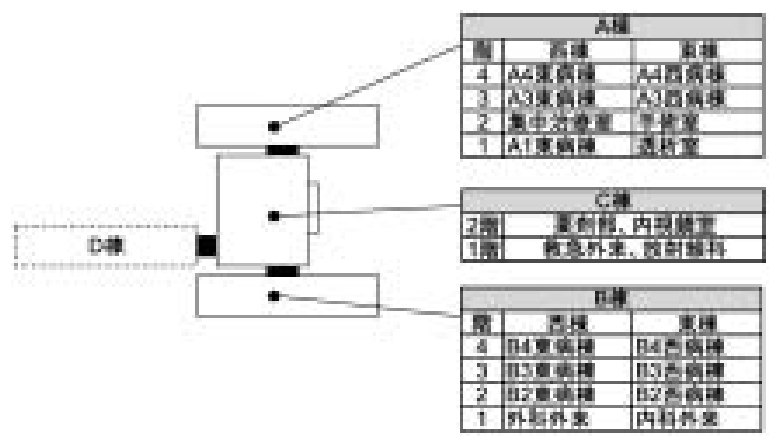

図 1 . 細菌学的環境調査を行った部署の略図

では死滅することと真菌は菌種によって培養可能な培地 が異なることから，好気的培養が可能な細菌を調査対象 とした . 清掃の影響を考慮して調査は清掃前に行った . 入院病棟の空中浮遊菌検査は処置室, 病室, 廊下で行っ た . 空気 200L をエアーサンプラーMas-100(メルク(株)) を用いてハート・インフュージョン寒天培地(栄研化学 (株))に吹き付(たた ${ }^{9,10}$. 入院病棟の床の拭き取り検査は 処置室, 病室, 廊下, トイレ, 洗面所, ナースステー ションで行った，床 $100 \mathrm{~cm}^{2}$ を綿棒で拭った . 綿棒に付 着した細菌を滅菌生理食塩水 $1 \mathrm{~mL}$ に懸濁させた。光の 懸濁液 $0.1 \mathrm{~mL}$ をハート・インフュージョン寒天培地に 塗布した、入院病棟の流しの拭き取り検査は洗面所 ,ナー スステーションで行った . 流しの排水口の周囲を綿棒で 拭った。綿棒に付着した細菌を滅菌生理食塩水 $1 \mathrm{~mL}$ に 懸濁させた . 帯の懸濁液 $0.1 \mathrm{~mL}$ をハート・インフュー ジョン寒天培地とマンニット食塩寒天培地(オキソイド) におのおの塗布した . 入院病棟以外の谷の他の部署は， その部署の施設の構造に応じて入院病棟と同樣に空中浮 遊菌検査，床の拭き取り検査や流しの拭き取り検査を 行った。サンプルを接種した寒天培地は $37^{\circ} \mathrm{C}, 2$ 日間培 養し, 生育したコロニーをカウントして菌数 colony forming unite(cfu)を算出した .

\section{3. 菌種同定と分子疫学的解析}

分離し, 純培養した菌株はグラム染色後, 以下の手順 により同定した .グラム陽性球菌(GPC)はマンニット食 塩寒天培地上での生育とマンニット分解性を観察し, 生 化学的同定キットである A piSTAPH(日本ビオメリュー (株))にて菌種を決定した．MRSA は黄色ブドウ球菌の うち， $4 \% \mathrm{NaCl}$ (和光純薬工業(株))， $6 \mu \mathrm{g} / \mathrm{mL}$ の才キサ シリン(シグマ・アルドリッチ ジャパン(株))含有ミュー ラー・ヒントン寒天培地(オキソイド)上の増殖で判定し た.グラム陰性桿菌(GNB)はOF試験(栄研化学(株))の 後 , A pi $20 \mathrm{E}$ や A pi $20 \mathrm{NE}$ (日本ビオメリュー(株))で菌種 を決定した .グラム陽性桿菌(GPB)はグラム染色性と細 菌およびコロニーの形態により GPB とした . 


\section{結果}

1. 空中浮遊菌検査, 床および流しの拭き取り検査にお ける平均検出菌数の年次推移

1999 年から 2004 年の空中浮遊菌検査, 床および流し の拭き取り検査における平均検出菌数の推移を図 2 に示 した . 空中浮遊菌検査では平均 $38 \pm 45.8 \mathrm{cfu} / 200 \mathrm{~L}$ の細 菌が検出された . 2000 年に菌数が減少したものの，2001 年から 2003 年には約 2 倍に増加し，2004 年には再び減 少した . 床の拭き取り検査では, 平均 648 $1200.8 \mathrm{cfu/}$ $100 \mathrm{~cm}^{2}$ の細菌が検出された . 1999年から 2001 年にか けて減少していたが，2002年に増加し，2004年には再 び増加した . 流しの拭き取り検査では平均 $4.8 \times 10^{6} \pm 1.1$ $\times 10^{7} \mathrm{cfu} / \mathrm{swab}$ の細菌が検出された . 平均検出菌数は調 査した隔年で増加と減少を繰り返した. 空中浮遊菌検 査，床および流しの拭き取り検査における年度間の増減 は, 空中・床・流しの各検査間で同調していなかった 。

\section{2. 各部署の平均検出菌数の年次推移}

各部署における空中浮遊菌検査, 床および流しの拭き 取り検査の平均検出菌数を表 1-3 に示した. 空中浮遊菌 検査，床および流しの拭き取り検査において，弚の他の
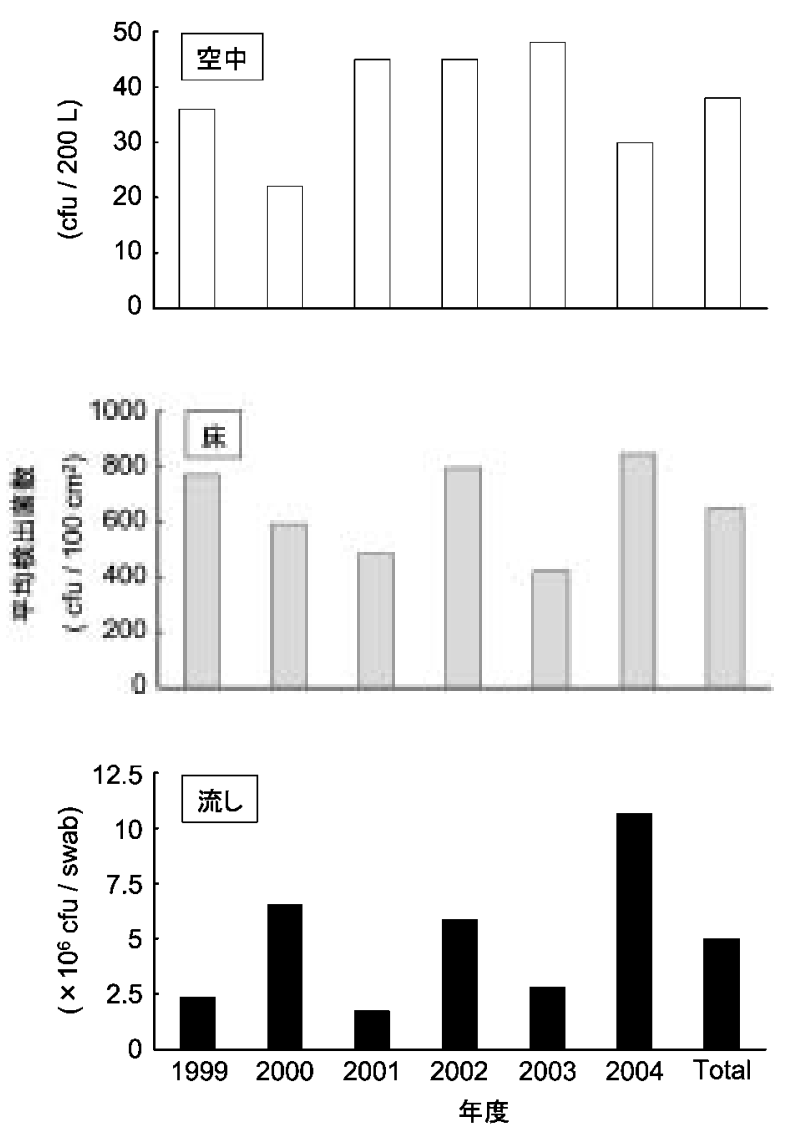

図 2. 空中浮遊菌検査, 床および流しの拭き取り 検査の平均検出菌数の年次推移
病院施設は $A \cdot B$ 入院病棟よりも平均検出菌数が少な かった .また，床および流しの拭き取り検査においては $\mathrm{A}$ 入院病棟よりもB 入院病棟の平均検出菌数のほうが 多かった . 空中浮遊菌検査において, 2001年は多くの 入院病棟(A 1東, A 3 東, A 3 西, A 4 東, A 4西, B 3 東, B 3 西, B 4東と B 4西)で平均検出菌数が増加し, 2000 年に比べ多い部署では 9.1倍に増加していた . 手術 室, 薬斉部と集中治療室は光の他の病院施設と比較して 毎年検出菌数が低い傾向にあった . 床の拭き取り検査に おいて，2002年は検査したすべての入院病棟で平均検 出菌数が増加し，2001 年に比べ多い部署では 30.0 倍に 増加していた . 流しの拭き取り検査において, 薬阂部と

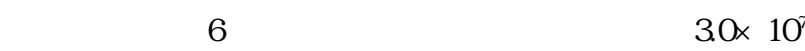
$\pm 2.6 \times 10^{7} \mathrm{cfu} / \mathrm{swab}$ と $1.0 \times 10^{7} \pm 1.3 \times 10^{7} \mathrm{cfu} / \mathrm{swab}$ であり， 兴の他の病院施設の $2.3 \times 10^{5} \pm 1.4 \times 10^{6} \mathrm{cfu} / \mathrm{swab}$ よりも 極めて多かった . 空中浮遊菌検査，床および流しの拭き 取り検査内で観察すると, 分離菌数が多い年はある特定 の場所か数百倍に突出して多くなったのではなく，離れ ている場所であってもほとんどの調査場所て増加してい た。

\section{3. 分離菌種の推移}

6 年間の細菌学的環境調査で分離した 3,862 株のグラ 么染色性と形態あるいは菌種を図 $\mathbf{3}$ に示した . グラム陽 性球菌は環境細菌であるミクロコッカス属菌やヒトや動 物の体表に存在するスタフィロコッカス属菌が大部分で あった . スタフィロコッカス属菌の中では, Staphylococcus (S.) aureus ,S. capitis ,S. epidermidis, S. haemolyticusや S. hominis などが多かった.MSSA と MRSA を含めたグ ラム陽性球菌の割合は 1999 年に全体の $40 \%$ 程度 , 2002 年には $50 \%$ を超え，2003 年と 2004 年には若干減少し たが，6年間では約 53\% であった .グラム陰性桿菌は 腸内細菌科に属するエンテロバクター属菌やブドウ糖非 発酵のアシネトバクター属菌とシュードモナス属菌で あった、菌種では, Enterobacter cloacae, Acinetobacter junii, Pseudomonas aeruginosa, Burkholderia cepacia や Stenotrophomonas maltophila などが多かった .グラム陰 性桿菌の割合は 1999 年には $30 \%$ 程度であったが， 2002 年には $5 \%$ に満たなかった . 弚の後，2004年には $15 \%$ を超えるまで増加した . グラム陽性桿菌はほとんどが土 壤細菌で芽胞を形成するバシラス属菌であった .グラム 陽性桿菌の割合は毎年 $30 \%$ 前後で増減していた.MRSA と緑膿菌に注目すると，6年間の調査でおのおの 59 株， 107 株が分離され, 2002 年に分離割合, 分離菌数(とも に3株)が最も少なかった．また，空中浮遊菌検査，床 および流しの拭き取り検査のMRSA と緑膿菌の分離場 所を図 4 に示した。MRSA は空中浮遊菌検査，床およ び流しの拭き取り検査から分離されたが, 兴の大部分が 
表 1. 各部署における空中浮遊菌検査の平均分離菌数の年次推移

\begin{tabular}{|c|c|c|c|c|c|c|c|}
\hline 部署 & 1999 & 2000 & 2001 & 2002 & 2003 & 2004 & 総平均 \\
\hline A1 東 & 7 & 14 & 24 & N.T. & N. T. & N. T. & 15 \\
\hline A3 東 & 46 & 18 & 32 & 59 & 34 & 17 & 34 \\
\hline A3 西 & 55 & 9 & 82 & 46 & 71 & 25 & 48 \\
\hline A4 東 & 34 & 31 & 156 & 68 & 22 & 15 & 58 \\
\hline A4 西 & 83 & 22 & 32 & 37 & 70 & 15 & 44 \\
\hline B2 東 & 33 & 28 & 26 & 69 & 57 & 67 & 47 \\
\hline B2 西 & 55 & 27 & 27 & 74 & 29 & 41 & 42 \\
\hline B3 東 & 108 & 18 & 90 & 72 & 55 & 46 & 65 \\
\hline B3 西 & 50 & 17 & 22 & 69 & 19 & 41 & 36 \\
\hline B4 東 & 44 & 28 & 85 & 64 & 35 & 43 & 50 \\
\hline B4 西 & 32 & 25 & 132 & N. T. & N. T. & N. T. & 63 \\
\hline 放射線科 & 47 & 25 & 9 & 41 & 77 & 24 & 40 \\
\hline 手術室 & 5 & 5 & 6 & 20 & 38 & 18 & 16 \\
\hline 内視鏡室 & 23 & 10 & 42 & 16 & 41 & N. T. & 27 \\
\hline 外来 & 32 & 72 & 20 & 42 & 41 & 12 & 36 \\
\hline 廊下 & 31 & 18 & 47 & 81 & 83 & 60 & 56 \\
\hline 透析室 & 68 & 17 & 32 & 69 & 75 & 57 & 51 \\
\hline 薬剤部 & N. T. & 1 & 0 & 17 & 8 & 10 & 7 \\
\hline 救急外来 & 16 & 13 & 125 & 51 & 50 & 15 & 45 \\
\hline 集中治療室 & 9 & 20 & 15 & 12 & 20 & 25 & 17 \\
\hline A 棟入院病棟 & 47 & 19 & 69 & 53 & 49 & 18 & 43 \\
\hline B 棟入院病棟 & 54 & 24 & 64 & 69 & 39 & 48 & 49 \\
\hline その他の病院施設 & 23 & 23 & 24 & 36 & 51 & 26 & 32 \\
\hline
\end{tabular}

单位; cfu/200 L

N. T.; not tested

表 2 . 各部署における床の拭き取り検査の平均分離菌数の年次推移

\begin{tabular}{|c|c|c|c|c|c|c|c|}
\hline 部署 & 1999 & 2000 & 2001 & 2002 & 2003 & 2004 & 総平均 \\
\hline A1 東 & 284 & 108 & 38 & N. T. & N. T. & N.T. & 135 \\
\hline A3 東 & 1,322 & 468 & 343 & 1,020 & 260 & 758 & 695 \\
\hline A3 西 & 810 & 772 & 777 & 2,008 & 712 & 842 & 1,050 \\
\hline A4 東 & 1,939 & 715 & 1,053 & 1,426 & 244 & 2,600 & 1,294 \\
\hline A4 西 & 341 & 202 & 61 & 806 & 354 & 230 & 308 \\
\hline B2 東 & 962 & 2,473 & 83 & 2,490 & 310 & 483 & 1,150 \\
\hline B2 西 & 620 & 883 & 577 & 3,160 & 544 & 1,784 & 1,210 \\
\hline B3 東 & 565 & 292 & 688 & 1,122 & 312 & 464 & 568 \\
\hline B3 西 & 1,138 & 2,182 & 557 & 1,210 & 360 & 966 & 1,085 \\
\hline B4 東 & 1,048 & 253 & 127 & 960 & 140 & 984 & 589 \\
\hline B4 西 & 2,098 & 760 & 1,632 & N. T. & N. T. & N. T. & 1,461 \\
\hline 放射線科 & 581 & 536 & 558 & 376 & 726 & 468 & 540 \\
\hline 手術室 & 83 & 84 & 505 & 91 & 406 & 724 & 307 \\
\hline 内視鏡室 & 83 & 330 & 0 & 213 & 210 & N. T. & 168 \\
\hline 外来 & 946 & 320 & 74 & 182 & 254 & 2,087 & 520 \\
\hline 廊下 & 1,666 & 367 & 1,233 & 251 & 641 & 483 & 804 \\
\hline 透析室 & 50 & 40 & 40 & 120 & 1,205 & 745 & 432 \\
\hline 薬剂部 & 285 & 35 & 0 & 0 & 35 & N. T. & 71 \\
\hline 救急外来 & 213 & 523 & 48 & 285 & 423 & 280 & 296 \\
\hline 集中治療室 & 397 & 260 & 52 & 135 & 132 & 922 & 299 \\
\hline A 棟入院病棟 & 953 & 453 & 449 & 1,315 & 393 & 1,044 & 731 \\
\hline B 棟入院病棟 & 1,043 & 1141 & 611 & 1,802 & 341 & 955 & 971 \\
\hline その他の病院施設 & 524 & 301 & 417 & 201 & 464 & 708 & 429 \\
\hline
\end{tabular}

単位; cfu/ $100 \mathrm{~cm}^{2}$

N. T.; not tested

床の拭き取り検査(68.8\%)から分離された . 緑膿菌は空 中浮遊菌検查からは分離されず，床の拭き取り検査から 11 株(10.3\%)，流しの拭き取り検査から 96 株(89.7\%)分 離された . 両菌とも光の他の病院施設よりもナースス テーション, 病室や廊下などの入院病棟からの分離が多 かった．また，MRSA と緑膿菌の分離は各診療科(入院
病棟)の間で分離菌数に大きな差がなかった .

考察

本研究では, 病院内で感染制御を目的とした細菌学的 環境調査を 6 年間行った . 院内の環境細菌の分布を調査 
表 3 . 各部署における流しの拭き取り検査の平均分離菌数の年次推移

\begin{tabular}{|c|c|c|c|c|c|c|c|}
\hline 部署 & 1999 & 2000 & 2001 & 2002 & 2003 & 2004 & 総平均 \\
\hline A1 東 & 180,000 & 105,750 & 169,000 & N. T. & N. T. & N. T. & 145,900 \\
\hline A3 東 & 50,300 & $2,620,700$ & 135,350 & $1,226,000$ & 529,600 & $3,852,900$ & $1,402,475$ \\
\hline A3 西 & 100,000 & $1,217,550$ & $2,029,385$ & 140,000 & 29,150 & $11,895,000$ & $2,568,514$ \\
\hline A4 東 & $5,500,000$ & 90,025 & 12,295 & $11,120,000$ & 535,405 & $31,755,000$ & $8,168,788$ \\
\hline A4 西 & $1,600,000$ & $2,225,000$ & 549,467 & $3,885,000$ & $5,570,680$ & $22,760,000$ & $5,380,697$ \\
\hline B2 東 & 515,000 & 19,250 & $5,834,885$ & $4,835,000$ & 218,650 & $5,200,240$ & $2,770,504$ \\
\hline B2 西 & $5,500,000$ & $21,600,000$ & 592,005 & $5,045,000$ & $9,826,445$ & $16,320,000$ & $9,813,908$ \\
\hline B3 東 & $5,500,000$ & $3,940,000$ & $4,630,750$ & $20,170,000$ & 726,000 & $3,810,000$ & $6,462,792$ \\
\hline B3 西 & 502,700 & 959,250 & 4,415 & $2,133,500$ & $13,885,000$ & $16,175,000$ & $5,609,978$ \\
\hline B4 東 & $5,950,000$ & $30,550,110$ & 17,085 & $13,371,000$ & 50,095 & $11,050,000$ & $10,164,715$ \\
\hline B4 西 & $5,001,500$ & 495,250 & 432,385 & N. T. & N. T. & N. T. & $1,976,378$ \\
\hline 放射線科 & 0 & 20 & N. T. & 10 & 1,550 & 1,300 & 576 \\
\hline 手術室 & 52,000 & 140 & 0 & 18,855 & 150 & 150 & 10,040 \\
\hline 内視鏡室 & 590 & N. T. & 240 & 560 & 0 & N. T. & 348 \\
\hline 外来 & $3,336,510$ & 600 & 212,090 & 3,468 & 71,375 & 10 & 399,559 \\
\hline 透析室 & N. T. & N. T. & N. T. & 6,700 & 0 & 3,120 & 3,273 \\
\hline 薬剂部 & $2,000,000$ & $66,900,00$ & $2,080,000$ & $34,240,000$ & $22,020,000$ & $53,520,000$ & $30,126,667$ \\
\hline 救急外来 & $3,000,000$ & 30 & 1,630 & 0 & 450 & 0 & 500,352 \\
\hline 集中治療室 & 100,000 & $1,710,000$ & $25,760,000$ & $2,9240,000$ & $5,180,000$ & 260 & $10,331,710$ \\
\hline$A$ 棟入院病棟 & $1,628,060$ & $1,251,805$ & 576,405 & $4,092,750$ & $1,666,209$ & $17,565,725$ & $4,031,574$ \\
\hline B 棟入院病棟 & $3,828,200$ & $9,593,977$ & $1,918,588$ & $9,110,900$ & $4,941,238$ & $10,511,048$ & $6,510,925$ \\
\hline その他の病院施設 & $1,378,379$ & $8,576,628$ & $2,848,573$ & $4,554,918$ & $1,963,453$ & $5,352,636$ & $3,836,485$ \\
\hline
\end{tabular}

N. T.; not tested

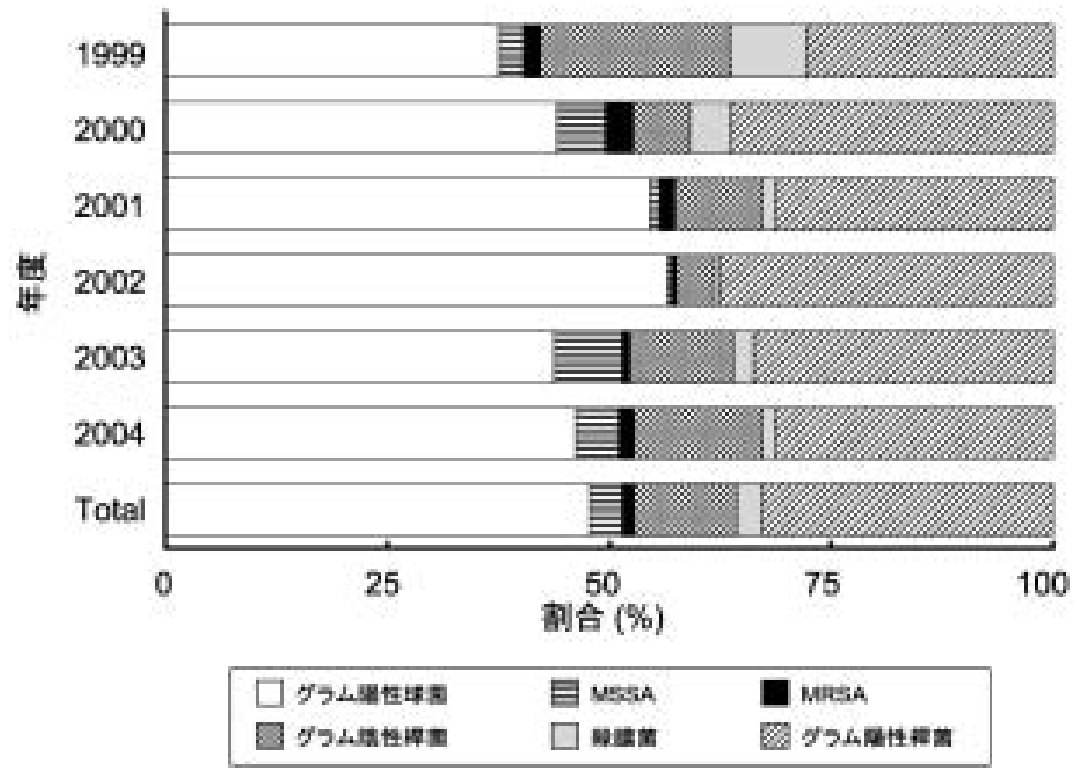

図 3. 各年度の分離菌種の推移

し,分離菌数の推移および部署ごとに比較した .また，分 離菌種を同定し，菌種の推移および院内感染・日和見感 染に関与する MRSA と緑膿菌の分布について調査した .

空中浮遊菌検査，床および流しの拭き取り検査の平均 分離菌数において，年度間の増減は各検査間で非同調性 であったが(図 1)，各検査内では同調していた(表 1-3) . そのため, 空中・床・流しの污染あるいは清浄化は他の 項目の影響を受けずに独立しているが，環境細菌の分布 は, 空中・床・流しの同じ項目内で病院全体として同じ
増加または減少する方向に推移していることが明らかに なった 。

各部署における空中浮遊菌検査，床の拭き取り検査お よび流しの拭き取り検査の年次推移では，A 入院病棟， $\mathrm{B}$ 入院病棟と关の他の病院施設の間に検出菌数の差が観 察された . 入院病棟はほぼ特定の患者，患者の家族や医 療従事者がおり，患者は生活をしている．一方，弚の他 の病院施設は，医療従事者は特定しているが，患者は不 特定多数で, 限られた時間のみの使用である . 入院病棟 


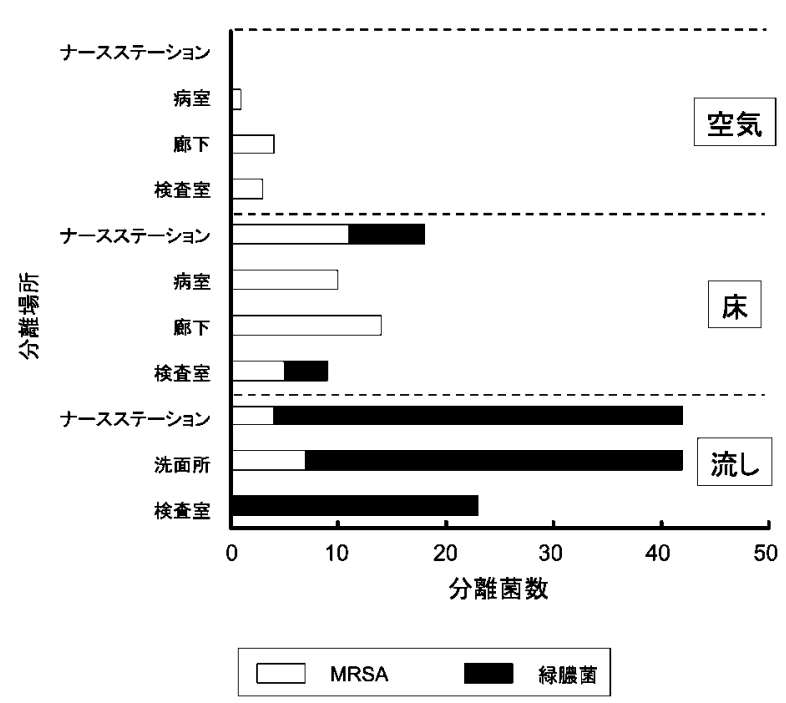

図 4.MRSA と緑膿菌の調査場所別分離菌数

では, A 棟は3階と4階が，B 棟は3階から5階が入院 病棟であるため，B 棟のほうがベッド数が約 1.5倍多 い.また, A 病棟は入院病棟以外に手術室(2階), 集中 治療室と透析室(ともに 1階)があるが, B 病棟は 1階が 一日平均約 1400 人が訪れる外来である(図 1). 弚のた め, $\mathrm{A}$ 入院病棟と $\mathrm{B}$ 入院病棟の検出菌数の差は, $\mathrm{A}$ 病 棟よりもB病棟のほうがヒトの動きが棟全体として活 発であることか影響していると考えられた .これらのこ とから，環境細菌の分布はヒトの使用時間とヒトの動向 に左右されることが明らかになった . 流しの拭き取り検 査において, 薬阁部と集中治療室て顕著に分離菌数が多 かったが，後の聞き取り調査によると，調査した流しは 輸液などを廃棄する流しであり，輸液に含まれる豊富な 栄養分により過剩に細菌が生育していたと考えられた (表 3) . これらは医療従事者のみが使用する流しである が, 衛生的な環境保全の観点から, 現在は輸液を廃棄し た後の洗浄や日常的な洗浄に留意している.

分離菌種の推移において, 2002 年はグラム陽性球菌 とグラム陽性桿菌の増加に伴いグラム陰性桿菌の減少の ため割合の変化か顕著であったが(図 3), 弚の原因とし て，2002年の新病棟(D 棟)の開設が考えられた(図 1) . 新病棟建設中(2001 年)の入院病棟での空中浮遊菌が増加 し, 開設直後(2002年)の床表面付着菌か増加していた(表 1，2）. また，新病棟への連絡通路に最も近いB 2 東 · 西病棟の 2002 年の空中浮遊菌数および床表面付着菌数 は 6 年間で最も多かった(表 1，2).この細菌学的環境調 査を行った期間では，手指の消毒法と清掃職員による清 掃方法や清掃回数に変化はなかった . 兴のため, この菌 種と分離菌数の変化は新病棟の建設開局に伴い, 機器の 搬入やヒトの移動による外環境からの空気の流入，粉塵 の増加を示しており，空中および床から主に分離される
グラム陽性桿菌と球菌の増加をもたらした結果，菌種の 割合に変化が生じたと推測された。MRSA と緑膿菌の 分布の違いは(図 4)，両菌の性質に起因すると考えられ た．黄色ブドウ球菌はヒトを含めた動物の体表常在菌で あり,一方, 緑膿菌は水分の多い環境に分布している。 弚のため, MRSA は主に床から，緑膿菌は主に流しか ら分離されたと考えられた。MRSA は空中浮遊菌検査 において，医療従事者のみの空間であるナースステー ションの空気からは分離されず，患者と医療従事者の共 有空間である病室，廊下や検査室から分離された，床や 流しの拭き取り検査においては, ナースステーションの 床からの分離数よりも病室の床のほうが若干少なかった が，医療従事者よりも患者の使用頻度が高い廊下および 洗面所からの分離が多かった，乥のため，MRSAの感染 制御には処置前後の手指消毒の励行などの患者との接し 方に重点を置く必要性が挙げられた，一方，緑膿菌は分 離株の大部分が流しから分離され，患者の使用頻度が高 い病室，廊下からは分離されなかったことから，緑膿菌 の感染制御には，環境の衛生化などの医療従事者と環境 との接し方に重点を置く必要性が挙げられた .グラム陰 性菌の中で多く分離された Enterobacter cloacae はヒト の腸管内の常在菌であり,Pseudomonas aeruginosa ,Burkholderia cepacia やStenotrophomonas maltophila は自 然 環境に広く分布している細菌であるが，日和見感染原因 菌でもあるため, これらの細菌が分離された流しの清掃 や消毒が必要である.しかし, Pseudomonas aeruginosa， Burkholderia cepacia やStenotrophomonas maltophila は 消毒薬からの検出も報告されており11-18)，清掃や消毒の 際に使用する薬斉の濃度にも留意する必要があると考え られた。

本研究から病院環境細菌の分布は個々の部署で独立し ているのではなく，病院全体で推移し，ヒトの動向や環 境の変化に影響を受けることが明らかになった . 弚のた め，個々の部署で環境の衛生化を图るのではなく病院全 体で取り組むことが必要である．また，本研究を通じて 空気 $200 \mathrm{~L}$ あたり約 40 個，床 $100 \mathrm{~cm}^{2}$ あたり約 650 個， 流し 1綿棒あたり約 500 万個の細菌が存在し，MRSA や緑膿菌がどこに多く分布しているかを知ることが出来 た .これらは日常の業務の中で感染リスクの減少を図る ことが出来る情報である.この研究は 1999 年から 6 年 間，毎年行ってきた．医療従事者の間では，調査開始当 初は調査されること, 結果が示されることに多少の抵抗 感があったが, 弚の結果として，流し付近の整理整頓や 頻回清掃などの衛生的な環境保全に向けた努力が各部署 にみられ，環境に対する意識の変化が感じられた．衛生 的な環境保全，環境細菌の分布を知るうえでも細菌学的 環境調査を行うことは有用であると考えられた． 


\section{引用文献}

1) C. Casolari, M. Pecorari, G. Fabio, S. Cattani, C. Venturelli, L. Piccinini, M.G. Tamassia, W. Gennari, A.M. Sabbatini, G. Leporati, P. Marchegiano, F. Rumpianesi, F. Ferrari, A simultaneous outbreak of Serratia marcescens and Klebsiella pneumoniae in a neonatal intensive care unit, J. Hosp. Infect., 61, 312-320 (2005).

2) S.S. Ghazal, K. Al-Mudaimeegh, E.M. AI Fakihi, A.T. A sery, Outbreak of Burkholderia cepacia bacteremia in immunocompetent children caused by contaminated nebulized sulbutamol in Saudi Arabia, Am. J. Infect. Control, 34, 394-398 (2006).

3) J.P. Flaherty, S. GarciaHouchins, R. Chudy, P.M. A rnow, An outbreak of gram-negative bacteremia traced to contaminated O-rings in reprocessed dialyzers, Ann. Intern. Med ., 119, 1072-1078 (1993).

4) L. Sehulster, R.Y. Chinn, Guidelines for environmental infection control in health-care facilities. Recommenda tions of CDC and the Healthcare Infection Control Practices Advisory Committee (HICPAC), MMWR Recomm. Rep., 52, 1-42 (2003).

5) I. Dakic, D. Morrison, D. Vukovic, B. Savic, A. Shittu, P. Jezek, T. Hauschild, S. Stepanovic, Isolation and molecular characterization of Staphylococcus sciuri in the hospital environment, J. Clin. Microbiol., 43, 2782-2785 (2005).

6) M. McGuckin, B., S. G. Kelsen, Surveillance in a surgical intensive care unit: patient and environment, Infect. Control , 2, 21-25 (1981).

7) C.S. Li, P.A. Hou, Bioaerosol characteristics in hospital clean rooms, Sci. Total Environ ., 305, 169-176 (2003).

8) M. A ugustowska, J. Dutkiewicz, V ariability of airborne microflora in a hospital ward within a period of one year, Ann. Agric. Environ. Med., 13, 99-106 (2006).

9) E. Bouza, T. Pelaez, J. Perez-Molina, M. Marin, L. Alcala, B. Padilla, P. Munoz, P. Adan, B. Bove, M.J. Bueno, F. Grande, D. Puente, M.P. Rodriguez, M. Rodriguez-Creixems, D. Vigil, O. Cuevas, Demolition of a hospital building by controlled explosion : the impact on filamentous fungal load in internal and external air, J. Hosp. Infect., 52, 234-242 (2002).

10) D. Nesa, J. Lortholary, A. Bouakline, M. Bordes, J. Chandenier, F. Derouin, J.P. Gangneux, Comparative performance of impactor air samplers for quantification of fungal contamination, J. Hosp. Infect., 47, 149-155 (2001).

11) M.D. Shickman, L.B. Guze, M.L. Pearce, Bacteremia following cardiac catheterization; report of a case and studies on the source, N. Engl. J. Med., 260, 11641166 (1959).

12) N.A. Simmons, D.A. Gardner, Bacterial contamination of a phenolic disinfectant, $\mathrm{Br}$. Med. J., 2, 668-669 (1969).

13) P.L. Parrott, P.M. Terry, E.N. Whitworth, L.W. Frawley, R.S. Coble, I.K. Wachsmuth, J.E. McGowan, Jr, Pseudomonas aeruginosa peritonitis associated with contaminated poloxamer-iodine solution, Lancet, $\mathbf{2}$, 683-685 (1982).

14) M.J. Frank, W. Schaffner, Contaminated aqueous benzalkonium chloride. An unnecessary hospital infection hazard, JAMA, 236, 2418-2419 (1976).

15) R.L. Berkelman, S. Lewin, J.R. Allen, R.L. A nderson, L.D. Budnick, S. Shapiro, S. M. Friedman, P. Nicholas, R.S. Holzman, R.W. Haley, Pseudobacteremia attributed to contamination of povidone iodine with Pseudomonas cepacia, Ann. Intern. Med., 95, 32-63 (1981).

16) J.D. Sobel, N. Hashman, G. Reinherz, D. Merzbach, Nosocomial Pseudomonas cepacia infection associated with chlorhexidine contamination, Am. J. Med., 73, 183-186 (1982).

17) S. Oie, A. Kamiya, Microbial contamination of antiseptics and disinfectants, Am. J. Infect. Control, 24, 389395 (1996).

18) M.M. Wishart, T.V. Riley, Infection with Pseudomonas maltophilia hospital outbreak due to contaminated dis infectant, Med. J. Aust., 2, 710-712 (1976). 